\title{
一般口演 7
}

\section{咀嚼運動経路の代表パターンと側方咬合位の咬合接触状態との関係}

\author{
Relationship between Representative Pattern of Masticatory Path \\ and Occlusal Contacts during Lateral Excursion
}

○志賀博, 小林義典, 荒川一郎, 横山正起, 水内一恵

Hiroshi Shiga, Yoshinori Kobayashi, Ichiro Arakawa, Masaoki Yokoyama, Kazue Mizuuchi

\section{日本歯科大学生命歯学部歯科補綴学第 1 講座}

Department of Partial and Complete Denture,

The Nippon Dental University School of Life Dentistry at Tokyo

\section{I. 目的}

本研究の目的は, 咀嚼運動経路の代表パターンと側 方咬合位の咬合接触状態との関係を調べ, 健常者の咀 嚼運動経路における代表的な 2 種類のパターン間の咬 合接触状態の差異を明らかにすることである.

\section{II. 方法}

\section{1. 被験者}

被験者は, 20 歳代の日本歯科大学歯学部の学生と 職員の中から, 全身と咀噮系に臨床的な異常, また 咀嚼系に機能障害の徵候や症状の既往が認められ ず，歯冠全体の補綴修復処置が 1 歯以内でかつ咬合 面の一部の保存修復処置が 2 歯以内の有歯顎者 60 名 を選択した。

咀緭運動自動分析システムを用いて，片側ごとにチ ユーインガムを咀嚼させた時の運動経路の重ね合わ せと平均経路の表示を行い, 両側の運動経路のパター ンが中心咬合位から作業側に向かってスムーズに開 ロし，その後中心咬合位へ閉口するが，中心咬合位付 近の閉口路が convex を呈するパターン I（図 1）を示 した 13 名を $\mathrm{A}$ 群, 中心咬合位から非作業側に向かっ て開口後作業側へ向かい，その後中心咬合位へ閉口す るが, 中心咬合位付近の閉口路が convex を呈するパタ ーンIII（図 2）を示した 12 名をB 群, 片側がパターン

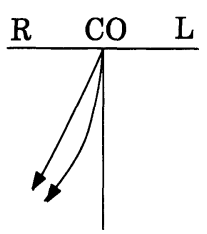

開口路
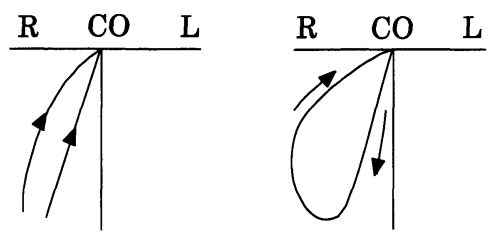

閉口路
図1 パターンI $\mathrm{CO}:$ 中心咬合位, $\mathrm{R}$ : 右側, $\mathrm{L}$ : 左側

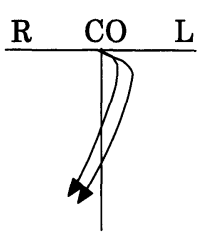

開口路

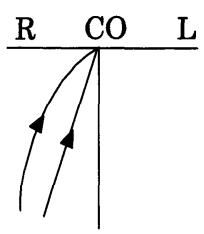

閉口路
図 2 パターンIII $\mathrm{CO}$ : 中心咬合位, $\mathrm{R}$ : 右側, $\mathrm{L}$ : 左側

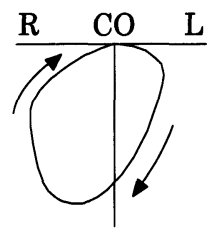

I , 他側がパターンIIII示した 3 名を C 群として分類 した.

\section{2. 被験食品}

被験食品は, ファイザー・コンシューマー・インク 社製のチューインガム 1 枚を記録前に約 1 分間咀喂さ せ，軟化したものを用いた. 


\section{3. 記録方法}

咀鱿運動は，片側ごとに 20 秒間行わせたチューイ ンガム咀嚼時の下顎切歯点の運動を MKG K6I を用い て記録した。 また，咬合接触状態は，下顎切歯点を中 心咬合位から側方へ $2 \mathrm{~mm}$ 滑走させた側方咬合位にお ける作業側と平衡側について, 厚さ $12.7 \mu \mathrm{m}$ のアルタ ス社製オクルーザルレジストレーションストリップ スによる引き抜き試験で調べた.

\section{4. 分析方法}

分析は, 各群ごとに側方咬合位における作業側と平 衡側の咬合接触部位の発現率を求め, その分布を Mann-Whitney 検定により, 各 2 パターン群間で比較し た. なお, 咬合接触部位は, 切歯部 (中切歯と側切歯), 犬歯部 (犬歯), 小臼歯部 (第 1 小臼歯と第 2 小臼歯), 大臼歯部（第 1 大臼歯と第 2 大田歯），切歯・ 犬歯部 (切歯部と犬歯部), 切歯・小臼歯部（切歯部之小臼歯 部), 切歯・大白歯部 (切歯部と大臼歯部), 犬歯・小 臼歯部（犬歯部之小臼歯部），犬歯・大臼歯部（犬歯 部と大臼歯部), 小臼歯・大臼歯部（小臼歯部と大臼 歯部), 切歯・犬歯・小臼歯部（切歯部と犬歯部と小 且歯部), 切歯 - 犬歯 - 大臼歯部（切歯部と犬歯部と 大臼歯部), 切歯 - 小臼歯 - 大臼歯部（切歯部と小目 歯部と大臼歯部), 犬歯・小田歯・大白歯部（犬歯部 と小臼歯部と大臼歯部), 切歯・犬歯 - 小田歯 - 大臼 歯部（切歯部と犬歯部と小臼歯部と大臼歯部）の 15 部位とした。

\section{III. 結果とまとめ}

\section{1. 作業側における咬合接触部位の発現率}

作業側における咬合接触部位の発現率は, A 群では, 犬歯部が $57 \%$ で最も高く, 以下犬歯・小臼歯部が $31 \%$, 小臼歯部が $12 \%$ の順であり, 犬歯部が全体の $90 \%$ \%を 占めた. 一方, B 群では, 犬歯・小臼歯・大臼歯部が $46 \%$ で最も高く, 以下小正歯・大白歯部が $21 \%$, 犬歯・ 小臼歯部が $16 \%$ ，小臼歯部が $8 \%$, 切歯・ 犬歯・ 小臼 歯部と切歯・犬歯・小臼歯・大臼歯部がそれぞれ $4 \%$ の順であり, 大臼歯部が全体の約 $70 \%$ を占め, $\mathrm{A}$ 群と 明確に異なった。 また， $\mathrm{C}$ 群では，犬歯部と犬歯・小 臼歯・大臼歯部がそれぞれ $33 \%$, 犬歯・小臼歯部と犬 歯・大臼歯部がそれぞれ $17 \%$ \%㐫，A 群と B 群の 両者の特徵を示した.

群間の比較では, $\mathrm{A}$ 群と $\mathrm{B}$ 群との間, $\mathrm{A}$ 群と $\mathrm{C}$ 群と の間にそれぞれ有意差が認められた。

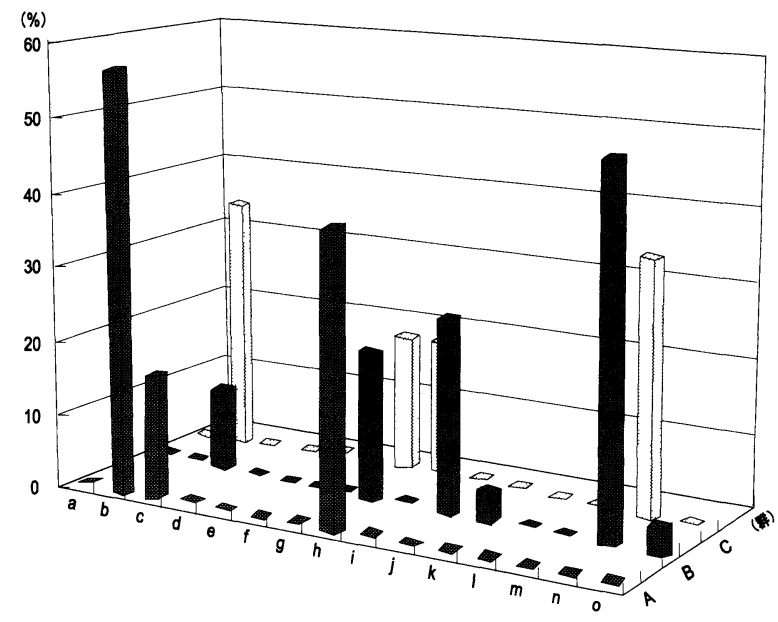

図 3 作業側における咬合接触部位の発現率 $\mathrm{a}$ : 切歯部, $\mathrm{b}$ : 犬歯部, $\mathrm{c}$ : 小臼歯部, $\mathrm{d}$ : 大白歯部, $\mathrm{e}$ : 切歯 - 犬歯部, $\mathrm{f}$ : 切歯・ 小臼歯部, $\mathrm{g}$ : 切歯 - 大臼歯部, $\mathrm{h}$ : 犬歯 - 小臼歯部, $\mathrm{i}:$ 犬歯 - 大臼歯部, $\mathrm{j}$ : 小臼歯 大臼歯部, $\mathrm{k}$ : 切歯 - 犬歯 - 小臼歯部, $\mathrm{l}:$ 切歯 - 犬歯 大臼歯部, $\mathrm{m}$ : 切歯・小臼歯・大白歯部, $\mathrm{n}$ : 犬歯・小 臼歯・大臼歯部， 0 : 切歯 · 犬歯・小臼歯・大臼歯部

\section{2. 平衡側における咬合接触部位の発現率}

平衡側における咬合接触部位の発現率は, $\mathrm{A}$ 群では, 接触部位なしが $100 \%$ であったが，B 群では，大臼歯 部が $58 \%$ で最も高く，以下小臼歯・大臼歯部が $21 \%$, 接触部位なしが $17 \%$, 切歯・大臼歯部が $4 \%$ の順であ り, 大臼歯部が全体の $83 \%$ を占め, A 群と明確に異な った．また， C 群では，大臼歯部と接触なしがそれぞ れ $50 \%$ \%゙あり, 作業側と同様に A 群と B 群の両者の 特徴を示した.

群間の比較では, $\mathrm{A}$ 群と $\mathrm{B}$ 群との間, $\mathrm{A}$ 群と $\mathrm{C}$ 群と の間にそれぞれ有意差が認められた.

これらのことから，側方咬合位の咬合接触部位は， 両側がパターン I を示す場合と両側がパターンIII を 有する場合とが明らかに異なり，両側がパターン I の 場合には，作業側では主に犬歯部であり，平衡側では ないが，両側がパターンIIIを示す場合には，作業側， 平衡側ともに主に大臼歯であることが示唆された。 